Hichem Dkhili, Northern Border University, Saudi Arabia, University of Jendouba, Tunisia

Lasaad Ben Dhiab, Northern Border University, Saudi Arabia

\title{
ENVIRONMENTAL MANAGEMENT EFFICIENCY OF GCC COUNTRIES: LINKING BETWEEN COMPOSITE INDEX OF ENVIRONMENTAL PERFORMANCE, SOCIO-POLITICAL AND ECONOMIC DIMENSIONS
}

Abstract. This paper summarizes the arguments and counterarguments within the scientific discussion on the issue of environmental performance. The investigation of the topic of the Composite Index of Environmental performance (CIEP) in the paper is carried out in the following logical sequence. The research is focused on the relationship between the composite index of environmental performances and the sociopolitical and economic elements of countries. Systematization literary sources and approaches for solving the problem of the influence of the integration of a composite Index of Environmental performance on the socio-political and economic dimensions. The paper presents the results of the empirical analysis with an econometric model which uses a composite index of environmental performance. The relevance of the decision of this scientific problem is that advanced and the methodological tools of the research methods try to measure the influence of Composite Index of Environmental performance model as a dependent variable on economic (technology, transportation, infrastructure, consumption of goods, international trade and tourism) and sociopolitical factors (democracy, freedom, transparency, and social policy) of countries. We used a generalized least squares estimation with a panel data from 6 countries observed during the period 2002-2016. Our results reveal that democracy, social policy, and transparency have a positive effect on environmental performance. Of the same, transport, infrastructure and tourism have a negative effect. The results of the research can be useful for countries, researchers and practitioners that try to improve the environmental performance with a good level of the social politico and economic dimensions. Finally, our results show that good environmental performance is related to the different characteristics of countries such as social, political and economics. And these results can be useful for countries to incorporate this valuable composite index in their objectives.

Keywords: composite index of environmental performance, sociopolitical characteristics, economic aspects, generalized least square estimation, GCC countries.

Introduction. Environmental issues are now a strategic challenge for countries. Reflected as a collective concern, that must be integrated into productive activities. Openness to environmental values and investments in pollution control equipment seems necessary to ensure the sustainability of industrial activities. Countries' response to external pressures and social challenges is also an innovative theme for thinking about strategy and economic analysis.

Many studies resumed environmental policy studies and therefore focused on analyzing their determinants of environmental performance towards different dimensions of countries such as sociopolitical, social and environmental.

Environmental performance is defined as a multidimensional concept that is difficult to measure because it relates to corporate pollution, energy consumption and various management programs implemented to reduce these impacts.

In this context, sustainable development is an ideal consensus aimed at promoting the environment and development; it helps to ensure the integration of the three dimensions that make up the economy,

Cite as: Dkhili, H., \& Dhiab, L. B. (2019). Environmental Management Efficiency of GCC Countries: Linking Between Composite Index of Environmental Performance, SocioPolitical and Economic Dimensions. Marketing and Management of Innovations, 1, 5769. http://doi.org/10.21272/mmi.2019.1-05 
H. Dkhili, L. B. Dhiab. Environmental Management Efficiency of GCC Countries: Linking Between Composite Index of Environmental Performance, Socio-Political and Economic Dimensions

society and the environment. The CIEP model was developed by Garcia Sanchez et al. In 2015, the main objective of which is to measure the environmental performance of countries based on 19 individual indicators divided into five dimensions, compiled in the final composite index. (2007), the Democracy Index (2007), the Corruption Index (2007), the World Health Organization (2007)

Academic research has used quantitative and/or organizational indicators to measure this performance without reaching a consensus on its interpretation.

Hence, the empirical results of previous studies confirmed the interdependence of socio-economic and socio-social factors and sustainable development. For example, the study of Almeida et al. (2017), Garcia-Sanchez, et al. (2015), Pablo-Romero et al. (2017), Al-mulali, et al. (2015), Ahmad et al. (2017) and Ozokku and Ozdemir (2017). As well as the results of the Salahodjaev study (2016), in which the impact of the sustainable environment was assessed by taking into account the variables of different control factors. The author concluded that environmental performance varies by GDP per capita.

At present, the fundamental question seems to look at the economic, social and political variables. This was the beginning of interest in developing a unified model that was not limited to the economy, social, political, human and environmental life.

Apparently, the paper of Cracolici et al. (2009) has tried to combine relevant economic and «noneconomic» (mainly social) aspects of a country's performance in an integrated logical framework. Murakami et al. (2015) propose that Public policies influence the environmental quality and economic factors.

Further, Welsch (2007) associates the life satisfaction approach to environmental valuation investigates. And present a contribution that extends the life satisfaction approach to a comprehensive welfare analysis by estimating not only the monetary benefits of air pollution abatement but also the associated costs in terms of income foregone.

This paper aims to explain the relationship between the composite indicator of environmental performance (CIEP) and its relation to the political, social and economic characteristics of the countries.

Finally, the current research presents environmental performance using the environmental composite index as a dependent variable with a focus on two dimensions: social, political and economic characteristics. It also measures environmental performance using the CIEP suggested by GarciaSanchez et al. (2015).

Therefore, the importance of research has been highlighted by measuring and explaining the environmental impact through many indicators and their relation to the economic characteristics of countries. In order to provide the necessary information and solutions that enable countries to achieve economic growth. This required to increase the attention to this aspect and to improve the quality of the environment versus the effects of economic development. Our problematic is: What is the relationship between the composite indicator of environmental performance (CIEP) and socio-political/economic dimensions?

Literature Review. The debate on the determinants of environmental performance is an objective issue that is not adequately explained in empirical research and in different contexts.

This research proposal was the starting point especially for the responsibilities entrusted to different countries in maintaining the continuity of their natural resources and preserving their environment, in order to support sustainable competitive advantage and to ensure sustainable development for future generations. In light of the economic and social development of countries, the conflict between economic growth and the environment has become more complex and clearer than ever before. (Almeida et al., 2017). Effectively, the relationship between economic growth and sustainability of ecosystems has been widely discussed in previous studies, while results remain controversial. 
H. Dkhili, L. B. Dhiab. Environmental Management Efficiency of GCC Countries: Linking Between Composite Index of Environmental Performance, Socio-Political and Economic Dimensions

The Almeida et al. (2017) study, which used single and composite indicators of environmental damage and the Environmental Kuznets Curve (EKC) hypothesis, adequately reflects the relationship between economic growth and ecological damage.

Through the results obtained, the study called for the importance of improving the framework of environmental policies that ensure long-term economic development. Then, it identified the economic and environmental impacts of human activities by continuously seeking powerful and effective tools that provide useful information for policy design aimed at improving the quality of life of citizens (Garcia Sanchez, et al., 2015).

In the same context, the Garcia-Sanchez et al., 2015 study indicates that social and environmental policy measures reduce environmental impact and mortality while increasing life expectancy. The researchers found that these rich countries tend to have better environmental quality and that population growth and intensification are factors that increase the driving force, limiting the quality of the environment in countries.

The empirical results of the study of Pablo Romero et al., 2017 on the nature of the relationship between economic growth and transport activities with energy consumption of the transport sector, show the elasticity of the use of transport energy, a turning point in improving the quality of the environment. For Al-mulali, et al. (2015) used an Environmental Kuznets Curve (EKC) hypothesis using country environmental data as an indicator. Experimental results have shown that energy consumption, urbanization and trade openness increase environmental damage through their positive impact on the environmental characteristics of all most countries and all income groups. Financial development also reduces environmental degradation. And conclude that, the relationship between bank loans and companies that invest in projects that are mostly environmentally friendly has been confirmed.

Some researchers have taken consumption-based indicators for the real sustainability of lifestyles (Peters, 2008; Tuckker et al., 2016); Wiedmann (2009) (Wiedmann and Barrett, 2013) Asici (2013) also explored the relationship between economic growth and pressure on nature from an environmental sustainability perspective. In his findings, he found a positive relationship between income and pressure on nature, and that increased trade leads to increased pressure on nature. As for the study of Ahmad et al.; 2017), which examined the hypothesis of environmental Kuznets Curve (EKC) hypothesis in Croatia for the period 1992-2011 which resulted in a negative correlation between carbon dioxide emissions and economic growth over the long term. The study of Ozoko and Ozdemir (2017) concerned the relationship between income and carbon dioxide emissions (in the context of the Kuznets Curve hypothesis) using two models: the first contains 26 countries with high-income levels and the second model 25 emerging countries.

Thus, the result of both models implied that environmental degradation could not be resolved automatically through economic growth.

In particular, the pilot study (Azam, 2016) investigated the impact of environmental degradation on carbon dioxide emissions on economic growth in 11 Asian countries between 1990 and 2011 and its empirical results showed that environmental degradation has a significant negative impact on economic growth. He further recommended that environmental degradation should be regulated. Tiba and Omri (2017) provided a comprehensive review of previous studies on the relationship between energy, environment and growth at the level of individual and regional studies covering the period from 1978 to 2014. For the study of Arora and Shi (2016), energy and real GDP in the United States using a multivariate variable model for the years 1973 to 2014.

Finally, Wang et al. (2016) was employed in a study of China's environmental performance (performance assessment index, 2014) on the idea of supporting the Sustainable Human Development Index (HSDI) as a means to modify the ten index (HDI) with the addition of an environmental dimension, 
H. Dkhili, L. B. Dhiab. Environmental Management Efficiency of GCC Countries: Linking Between Composite Index of Environmental Performance, Socio-Political and Economic Dimensions

and then there was a need for a better balance between social, economic and environmental objectives In order to reach a real indicator of sustainable development.

This paper aims to explain the relationship between the composite indicator of environmental performance (CIEP) and its relation to the political, social and economic characteristics of the countries. Otherwise, we provide an overview of the most important problems that hinder economic growth in light of the neglect of the environmental element within the communities and the disclosure of the most important economic, political and social characteristics that help improve the quality of environmental performance. Schultink (2000) advances that indices must define the comparative advantage of the natural resource base and measure the fundamental capacity to sustain production rates of natural resource goods and services used to create societal well-being. And propose representative indices that are critical in the identification of development goals and realistic for objectives and can be used to evaluate, select and implement sustainable development strategies and plans. Caviglia-Harris et al. (2009) test the validity of the EKC using the Ecological Footprint (EF). And discover that energy is largely responsible for the lack of an EKC relationship and that energy consumption levels would have to be cut by over $50 \%$ in order for a statistically significant EKC relationship to emerge from the data. Overall, these results suggest that growth alone will not lead to sustainable development.

The aim of this study is to explore the explanatory factors of the environmental performance compound by applying the CIEP model used by Garcia-Sanchez et al. (2015) in their study, which saw several applications of this indicator in different countries in the study of (2017) Almeida et al., Al-mulali, et al. (2015) and Ahmad et al. (2017), Ozokku and Ozdemir (2017).

The CIEP model is based on 19 individual indicators grouped into five dimensions, which are subsequently synthesized in the final composite indicator. The methodological process for creating the CIEP was structured around seven dimensions. In fact, Dobbie and Dail (2013) describe five key steps required in constructing a composite index. The composite environmental performance index (CIEP) model is calculated by a combination formula of five environmental dimensions, where the dimensions that react negatively to the negative were multiplied during addition. The assembly formula (1) is as follows:

$$
C I E P_{i}-\left[\left(D F_{i} * w D F\right) *(-1)\right]+\left\lceil\left(P_{i} * w P *(-1)\right)\right]+\left(S_{i} * w S\right)+\left[\left(E f_{i} * w E f *(-1)\right]+\left(A_{i} * w A\right)\right.
$$

As noted dimensions $(S)$ and $(A)$ have a strong positive correlation with environmental performance, while (DF), (P), and (E) dimensions reduce environmental quality. The power of leadership determines the set of elements that generate environmental stress and represent an increase in the consumption of natural resources, which can cause environmental disruption.

Pressure $(P)$ is consistent with factors caused by the driving force that changes the natural state of the resources available in general, resulting from economic activities, energy production, exploitation of natural resources, agriculture, etc.

Pressure on environmental performance also negatively impacts carbon dioxide emissions, energy use and production, cereal and agricultural production, fertilizer use and seizing marine life. State $S$ represents changes in natural elements, such as variability in the availability of natural resources, physical fatigue, and levels of pollution, accidents and natural disasters caused by increased pressure.

(EF) represents the environmental impact of human health on mortality or life expectancy.

(A) Environmental policies that have a negative correlation with pressure, which lead to the conclusion that actions are capable of reducing environmental pressure.

The CIEP is used as dependent variable in the present work rather than a single variable as more commonly used.

From the review of the literature and on the basis of the studies of Garcia-Sanchez et al. (2015), Ahmad et al. (2017), Ozokku and Ozdemir (2017), we have four single variables that are classified as 
H. Dkhili, L. B. Dhiab. Environmental Management Efficiency of GCC Countries: Linking Between Composite Index of Environmental Performance, Socio-Political and Economic Dimensions

sociopolitical factors and have a relationship with environmental performance. The variables studied are a democracy, freedom, transparency, and social policy.

Obiedkov et al. (2013) and Giannone (2010) used various indices and ratings describing democratic processes in countries around the world have been developed by international organizations. This document will be divided as follows. In what follows, we clarify the measures of the different variables used. Subsequently, the methodology used. Finally, we achieve the results and discussions and finish with a conclusion and implications. For Dahl et al. (1994), transnational actions affect all democratic countries in varying degrees. Congleton (1995) and Neumayer (2002) have explored the link between democracy and environmental policies. And they demonstrated a positive effect of democracy on environmental performance. Tarverdi (2018), Lopezand and Mitra (2000) had to examine the effect of corruption on environmental variables and emphasizing the significant impact of corruption on adoption and implementation of environmental policies.

Yet, the literature review had to show a positive effect between democracies on the environmental commitment of countries.

H1: Democracy implies positively environmental performance.

For Barrett and Graddy (2000), they found that political freedoms significantly improve environmental quality. And they result that freedoms have no effect. Payne. (1995), described a negative impact between freedom and environment performance. Based on the literature of review, our hypothesis is trying to explain the positive effect of freedom toward the environment performance:

$\mathrm{H} 2$ : Freedom implies positively environmental performance.

Several studies have taken into account the role of transparency toward environmental performance. Indeed, the goal of transparency is to protect performance through the communication of information concerning the ecology and the environment. Gupta (2010) concludes that the potential for transparency is most unrealized, particularly for the poorest countries. Mason (2008) states that transparency is a relevant factor in environmental governance assume a good attitude to improve the quality of the environment. The general concept of transparency is linked to the responsibility for institutional information:

H3: Transparency implies positively environmental performance.

Kerret and Shvartzvald (2014) found a positive effect between social policies and the two performances: human health and the ecosystem. O'Ryan et al. (2005) found evidence that social policies improve the quality of the environment and reduce poverty. Similarly, the results of Almeida et al. (2017) show a positive effect between social policies and environmental performance. For Wolsink (2010), social acceptance can be applied within other policy domains, such as climate change adaptation, and waste management. And these findings should be regarded together by decision makers (Wolsink 2010). On this basis, our third hypothesis expounds the link between social policy and environment performance:

H4: Social policy implies positively the environmental performance

Extensive research has identified the role of economic factors and their impacts on environmental performance. The Studies of Hansen and Wernerfelt (1989), York and Clark (2010), Xiao' (2013), Wolsink (2010), Bilgen (2014), Gil-Molto and Varvarigos (2013), had identified these economic factors through technology, transportation, infrastructure, consumption of goods, international trade and tourism.

For transport, most of the literature review demonstrate a negative effect between transport and environmental performance. The results of the study of Wolsink (2010), Chapman (2007), Hickman et al. (2010) and Xiao' (2013) prove this relationship. The transport sector causes pollution, while transport negatively influences environmental performance. Thus, our fourth hypothesis is:

H5: Transport implied negatively environmental performance. 
H. Dkhili, L. B. Dhiab. Environmental Management Efficiency of GCC Countries: Linking Between Composite Index of Environmental Performance, Socio-Political and Economic Dimensions

Benchekrounn and Chaudhuri (2014), Tol (2009), Barrett (2006) link technology to investments made with the development of clean technologies as underlined. They connect technology with the preservation of the environment. In this stage, our fifth hypothesis is:

H6: Technology implies positively environment performance.

A set of theoretical and applied studies had analyzed the quality of relationships between the impact of financial development, income, trade openness and urbanization on $\mathrm{CO} 2$ emissions. The studies of Fan et al. (2017) found a positive relationship between trade and environment performance. Boutabba (2014) had studied the existence and direction of a causal relationship between carbon emissions, financial development, economic growth, energy consumption and trade openness for India. The results suggest that there is evidence on the long-run and causal relationships between importing and environment performance and between exporting and environmental performance. Saidi and Mbarek (2017) examine the impact of financial development, income, trade openness, and urbanization on carbon dioxide emissions for the panel of emerging economies using the time series data over the period 1990 2013. These authors extract the results that Trade improves environmental quality by reducing the growth of energy pollutants. The activity of exporting exerts a negative impact on environmental performance. At the same time, importing had a positive effect on environmental performance. At this stage, through the review of the literature, our six and seven hypotheses are:

$\mathrm{H} 7$ : Importing countries implies positively environment performance;

H8: Exporting countries implies negatively environment performance.

Beladi et al. (2009) prove that tourism causes environmental damage. And add that tourists generate resource overconsumption, change the natural habitat, and cause pollution because they do not know behave responsibly. These findings were taken up by other authors as Dubois and Ceron (2006) and Kim, S., et al. (2017). In this context, our hypothesis is:

$\mathrm{H} 9$ : Tourism implies negatively environment performance.

Bond (1999) also evaluated the environmental impact of other forms of infrastructure in South Africa and concluded that all have negative impacts on the ecosystem. Lucas, K. (2011) presents a hypothesis about the connection between investment in infrastructure and environmental damage, considering the influence of the level of development of countries. The results of Agenor (2010) shown that infrastructure is nonlinearly related to the stock of public capital. Hence, our hypothesis is:

H10: Infrastructure implies negatively environment performance.

Methodology and research methods. We use a Panel data is analyzed, composed of 6 countries of the GCC countries (Saudi Arabia, United Arab Emirates, Kuwait, Bahrain, Qatar, and Oman) and 16 years (from 2001 to 2016) the variables of the study are summarized in table 1 below:

All variables are extracted from World Bank databases, except The indicators of a changing democracy are extracted from the «unified democracy». The variable freedom index has occurred from the Freedom House Index (FRH) (House 2014). Finally, the transparency variable was selected from the Global Competitiveness Index (GCI) website. According to the literature background, the exploratory models developed to explain the environmental performance of countries are presented below. They use the variables and the dummy variables presented in table 1.

The empirical strategy is based on a panel data analysis and used generalized least square (GLS) estimates, to check the soundness of the results. The double dimensions, individual (countries) and temporal (years), of our sample, oriented us towards the selection of panel data analysis. And we note that a previous work established to verify autocorrelation between variables, endogeneity, multicollinearity and heteroskedasticity. On the basis of these tests, the most appropriate estimate is the generalized least squares (GLS) estimate.

The first econometric model is based on factors that aggregate the selected variables according to the two dimensions studied: (i) sociopolitical characteristics and (ii) economic factors. 
H. Dkhili, L. B. Dhiab. Environmental Management Efficiency of GCC Countries: Linking Between Composite Index of Environmental Performance, Socio-Political and Economic Dimensions

Equation (1):

$\operatorname{CIEPT}_{i t}=\alpha+\beta_{1}$ socit $_{i t}+\beta_{2}$ econom $_{i t}+\varphi_{i}+\varphi_{t}+\varphi_{c}+\varphi_{s}+\varepsilon_{i t}$

Where ( $\mathrm{a}$ ) is constant, (i) is the individual countries, (t) is the time (year), (s) is the type of government efficiency. $\varphi_{i}, \varphi_{t}, \varphi \varphi_{c}$, and $\varphi_{s}$ are Dummy variables to measure individual countries, time, and type of government influence, respectively $\varepsilon_{i t}$ is a random effect. In this second econometric model, the selected variables are analyzed separately:

Equation (2):

CIEPT $_{i t}=\alpha+\beta_{1}$ demo $_{i t}+\beta_{2}$ free $_{i t}+\beta_{3}$ transpa $_{i t}+\varphi_{i}+\beta_{4}$ socpol $_{i t}+\beta_{5}$ tech $_{i t}+\beta_{6}$ transpo $_{i t}+\beta_{7}$ inf $_{i t}+$ $\beta_{8}$ consump $_{i t}+\beta_{9}$ imp $_{i t}+\beta_{10}$ ext $_{i t}+\beta_{11}$ tour $_{i t}+\varphi_{i}+\varphi_{t}+\varphi_{c}+\varphi_{s}+\varepsilon_{i t}$

For the Dummies, variables were used to analyze the possible effects of individual countries, times, continents, and political systems on environmental performance. The proposed standard economic equations are implemented in three different ways, the first, without social and political characteristic variables, the second method, without economic variables, and finally, the complete model. The dummies are used in all models in order to identify their respective effects on environmental performance.

Table 1. Definition of variables

\begin{tabular}{|c|c|c|c|c|c|}
\hline No & Variable & ID & Metric & $\begin{array}{l}\text { Excepted } \\
\text { correlation }\end{array}$ & Source \\
\hline \multirow[b]{2}{*}{1} & $\begin{array}{l}\text { Environnemental } \\
\text { performance }\end{array}$ & CIEP & \multirow{2}{*}{ See Garcia Sanchez et al. (2015) } & $\begin{array}{l}\text { Dependent } \\
\text { variable }\end{array}$ & \multirow{2}{*}{ Garcia Sanchez et al. (2015) } \\
\hline & $\begin{array}{l}\text { Sociopolitical } \\
\text { characteristics }\end{array}$ & socit & & + & \\
\hline 2 & Democracy level & Demo & Unified Democracy Scores & + & unified-democracy-scores.org \\
\hline 3 & Freedom index & free & Freedom House (FRH) & + & www.freedomhouse.org \\
\hline 4 & Transparency & transpa & $\begin{array}{l}\text { Corruption Perceptions Index } \\
\text { (CPI) }\end{array}$ & + & www.transparency.org \\
\hline 5 & Social policies & Socpol & \multirow{2}{*}{$\begin{array}{l}\text { Policies for social inclusion/equity } \\
\text { cluster averaged }\end{array}$} & \multirow{2}{*}{+} & \multirow{2}{*}{ www.worldbank.org } \\
\hline 6 & Economics factors & Econo & & & \\
\hline 7 & Technology & Tech & $\begin{array}{l}\text { Investment in research and } \\
\text { development ( } \% \text { of GDP) }\end{array}$ & $-/+$ & www.worldbank.org \\
\hline 8 & Transport & transpo & CO2 emissions from transport & - & www.worldbank.org \\
\hline 9 & Infrastructure & Infra & $\begin{array}{l}\text { The second pillar of the } \\
\text { Competitiveness Index }\end{array}$ & - & www.weforum.org \\
\hline 10 & Import & $\operatorname{Imp}$ & $\begin{array}{l}\text { The current value of imports of } \\
\text { goods and services }\end{array}$ & - & www.worldbank.org \\
\hline 11 & Export & Exp & $\begin{array}{l}\text { The current value of exports of } \\
\text { goods and services }\end{array}$ & + & www.worldbank.org \\
\hline 12 & Tourism & Tour & $\begin{array}{l}\text { International tourism, expenditures } \\
\text { (current US\$) }\end{array}$ & - & www.worldbank.org \\
\hline
\end{tabular}

Sources: compiled by the authors.

Results. In this part of results, first, we will prescribe the variables of our study as well as their measurements, and then secondly, we will test separately the 3 models, the first without the economic factors, the second without the socio-political factors and finally, the third one the complete model. We used statistically the generalized least square (GLS) estimates, to check the soundness of the results, and the Result of the Arellano-Bond estimation method. 
H. Dkhili, L. B. Dhiab. Environmental Management Efficiency of GCC Countries: Linking Between Composite Index of Environmental Performance, Socio-Political and Economic Dimensions

Table 2 reveals the descriptive results of the different variables of our study. The average level of CIEP is $54.317 \%$ while the average level of democracy is (20.027) with a maximum of (160.125) and a minimum of $(0.198)$. Freedom achieved an average of $(18.141 \%)$ with a minimum of $(13.915 \%)$ and a maximum of (33.667\%).

The average level of sociopolitical characteristics remains with an average of is (4.538\%); a maximum value of $(9.871 \%)$ while its minimum value is $(1.719 \%)$ Contrary to the transport, the average value seems to be satisfactory with a level of $(70.929 \%)$; its maximum value is $(97.527 \%)$ while its minimum value is $(7.968 \%)$ For the technology, the average value is $(20.809 \%)$; its minimum value is $(-2.424 \%)$ and $(74.822 \%)$ as maximum value. Finally, the Descriptive statistics results indicate respectable values for infrastructure and transparency. We find that the average value of infrastructure (infra) is $(68.968 \%$ ) and the maximum value is $(99.998 \%)$

Table 2. Statistics of variables

\begin{tabular}{|c|c|c|c|c|c|}
\hline Variable & Obs & Mean & Std. Dev. & Min & Max \\
\hline CIEP & 833 & 54,317 & 12,894 & 21,79 & 72.689 \\
\hline socit & 860 & 4,538 & 1,719 & 0,000 & 9,871 \\
\hline Demo & 788 & 20,027 & 24,110 & 0,198 & 160,125 \\
\hline free & 669 & 18,141 & 2,204 & 13,915 & 33,667 \\
\hline transpa & 790 & 20,809 & 10,177 & $-2,424$ & 74,822 \\
\hline socpol & 773 & 10,922 & 17,193 & $-70,457$ & 69,706 \\
\hline Econo & 803 & 4.122 & 0.990 & 0.0161 & 4.523 \\
\hline Tech & 878 & 20,809 & 10,177 & $-2,424$ & 74,822 \\
\hline transpo & 606 & 70,929 & 10,147 & 7,968 & 97,527 \\
\hline Infra & 491 & 68,968 & 24,132 & 6,002 & 99,998 \\
\hline Imp & 834 & 20,027 & 24,110 & 0,198 & 160,125 \\
\hline Exp & 867 & 30,736 & 29,644 & 0,008 & 98,27 \\
\hline
\end{tabular}

Sources: developed by the authors.

Table 3 shows the correlation coefficients between all the variables in our study thus, the results show that transparency (transpa), democracy (demo), social policies (socpol) and freedom (free) have strong positive correlations with environmental performance (CIEP); these variables are socio-political characteristics. In the economic dimension, infrastructure (infra) and technology (tech) also had positive correlations with the (CIEP)

Table 3. Correlation Matrix

\begin{tabular}{|c|c|c|c|c|c|c|c|c|c|c|c|c|}
\hline & CIEP & Socit & Demo & Free & Transpa & Socpol & Econo & Tech & Transpo & Infra & Imp & Exp \\
\hline CIEP & 1.00 & & & & & & & & & & & \\
\hline Socit & 0.55 & 1.00 & & & & & & & & & & \\
\hline Demo & 0.72 & 0.74 & 1.00 & & & & & & & & & \\
\hline Free & -0.67 & 0.63 & 0.70 & 1.00 & & & & & & & & \\
\hline Transpa & 0.55 & 0.61 & 0.73 & 0.80 & 1.00 & & & & & & & \\
\hline socpol & 0.55 & 0.58 & 0.57 & 0.47 & 0.61 & 1.00 & & & & & & \\
\hline Tour & -0.01 & -0.07 & 0.09 & -0.59 & 0.73 & -0.33 & 1.00 & & & & & \\
\hline Tech & 0.64 & 0.23 & 0.01 & -0.02 & 0.08 & -0.02 & 0.03 & 1.00 & & & & \\
\hline Transpo & 0.70 & 0.24 & 0.01 & -0.01 & 0.06 & -0.05 & 0.05 & 0.93 & 1.00 & & & \\
\hline Infra & 0.66 & 0.22 & 0.01 & 0.01 & 0.05 & -0.04 & 0.04 & 0.87 & 0.93 & 1.00 & & \\
\hline Imp & 0.67 & 0.24 & 0.01 & -0.01 & 0.06 & -0.04 & 0.03 & 0.94 & 0.95 & 0.91 & 1.00 & \\
\hline Exp & 0.31 & 0.04 & 0.05 & 0.30 & 0.09 & -0.16 & 0.10 & -0.21 & 0.27 & -0.11 & 0.92 & 1.00 \\
\hline
\end{tabular}

Sources: developed by the authors.

Results of the model (1): without social and political characteristic variables. Table 4 indicates that the 
H. Dkhili, L. B. Dhiab. Environmental Management Efficiency of GCC Countries: Linking Between Composite Index of Environmental Performance, Socio-Political and Economic Dimensions

independent variable is positively and significantly correlated with the CIEP index. This means that the level of CIEP of the last year acts positively on the current level of the other variables (infra and imp)

Results of the model (2): Without economic variables. The results of the second model shown in the table (4) reveal that the variables democracy (demo), transparency (transpa), social policies (socpol) and (free) freedom have positive effects on environmental quality; this means that both variables increase the environmental performance measured by CIEP.

Results of the model (3): The complete model. According to the results of the complete model (Model 3) proven in table (4), the variables democracy (demo), social policies (socpol) has a positive correlation with environmental quality, the social policies (socpol) variable, infrastructure (infra), import (imp) has a positive and strongly significant correlation with environmental performance. We conclude that the variables:

- Transport (transpo) and tourism (tour) have negative and significant correlations with environmental performance in all models.

- Import (imp) also has a strongly significant and positive effect on environmental performance in all three models. Export has a negative and strongly significant correlation with environmental performance in all three models.

Table 4. Result of Arellano-Bond estimation

\begin{tabular}{|c|c|c|c|c|c|c|}
\hline & \multicolumn{2}{|c|}{ Model (1) } & \multicolumn{2}{|c|}{ Model (2) } & \multicolumn{2}{|c|}{ Model (3) } \\
\hline Epi & Coef, & $z$ & Coef, & Z & Coef, & Z \\
\hline CIEP & 3,756 & $54,330^{* \star *}$ & 3,756 & 53,950 *** & 0,758 & $51,970^{\star \star *}$ \\
\hline socit & & & 2,002 & $2,910^{\star * *}$ & 0,002 & $2,860^{* * *}$ \\
\hline Demo & & & 3,187 & 2,789 & 0,000 & 3,200 \\
\hline free & & & 2,253 & 3,370 & 0,006 & 2,890 \\
\hline socpol & & & 2,456 & 3,760 & $-0,007$ & 0,900 \\
\hline transpa & $-0,001$ & $-1,500$ & & & 0,005 & 1,000 \\
\hline tour & 2,005 & $3,750^{\star * *}$ & & & $-0,041$ & $-0,310$ \\
\hline Tech & 1,008 & 0,670 & & & 0,139 & 1,260 \\
\hline transpo & 2,002 & $3,050^{\star * *}$ & & & $-0,010$ & 0,090 \\
\hline Infra & 1,046 & 2,780 & & & 2,048 & 0,490 \\
\hline Imp & 0,075 & 3,670 & & & 1,077 & 1,850 \\
\hline Exp & $-0,431$ & $-1,030$ & & & $-0,054$ & $-0,580$ \\
\hline cons & 10,831 & 11,587 & 13,335 & 11,228 & 11,981 & 13,430 \\
\hline Sargan test & 53.197 & & 51.197 & & 48.301 & \\
\hline Prob> chi 2 & 0.085 & & 0.090 & & 0.117 & \\
\hline AR (1) & -1.486 & & -1.484 & & -1.484 & \\
\hline Prob $>$ Z & 0.137 & & 0.137 & & 0.137 & \\
\hline AR (2) & 0.893 & & 0.894 & & 0.897 & \\
\hline Prob $>Z$ & 0.371 & & 0.371 & & 0.369 & \\
\hline Nbre of Obs & 970 & & 970 & & 970 & \\
\hline
\end{tabular}

Sources: developed by the authors.

Discussion. With regard to economic, social and environmental dimensions, findings indicate that environmental performance exerts a positive and significant effect on the import. In the same line of idea, countries with higher level of import are able to solve environmental problems since they have the necessary financial resource to protect environment toward less production.

Countries recording a high level of export will not improve the environmental performance condition. They have high levels of environmental damage due to the characteristics of the predominant economic activities. The use of energy was considered as the most factors disturbing environment quality. Energy consumption is recognized as more pollutant. It's for this reason that we introduce two variables that reflect the use of energy; we mean the total final energy consumption and renewable energy consumption. 
H. Dkhili, L. B. Dhiab. Environmental Management Efficiency of GCC Countries: Linking Between Composite Index of Environmental Performance, Socio-Political and Economic Dimensions

Empirical results indicate that the variables export use highly increase the environmental performance damage. These results are surprising since the use of energy deteriorates environmental quality.

However, it should be noted that the CIEP is an index which comprises objectives, policy categories and indicators corresponding to environmental health and ecosystem vitality. It's obvious that the use of energy especially not clean threatens environmental quality, but it can enhance socioeconomic conditions since it offers more opportunity for investment and consequently for employment.

Also, it's considered as a primary input for transport activities which makes easier the movement of passengers and products. Our results are similar to Cracolici et al, (2009), Scruggs, (1999), Swamy and Fikkert (2000), Garcia-Sanchez et al. (2015), Husted et al. (2017), Mukherjee and Chakraborty (2013), Caviglia-Harris et al. (2009) and Alt and Spitzeck (2016). Tourism and transport reduce the environmental quality of countries. International trade, represented by importing and exporting variables, proves that importing countries increase environmental quality and exporting countries decreasing environmental performance.

While infrastructure has a significant and positive impact on environmental performance, this relationship depends on the degree of commitment of countries to their local development, the encouragement of foreign direct investment and the industrial sector. This promotes the export of goods and products and increases pollution and directly destroys the environment.

Conclusions. The purpose of this paper is to identify the factors that affect environmental performance as measured by the CIEP, in contrast with socio-political factors and economic factors. The choice of the sample for the GCC countries is based on a lack of research in this area, a great evolution of the industrial sector with a high carbon emission rate. This economic landscape characterized by a territorial development of the transport sector with the infrastructure. In addition, strong growth for the tourism sector, we gave the idea to advance this theme and have the opportunity to focus on the state of the art of the relationship between socio-political and economic factors with the environmental performance measured by the CIEP.

The conclusion found for GCC countries proves a positive relationship between democracy, freedom, transparency, social policy, technology, importing and infrastructure. We found also, a negative relationship between transport, exporting and tourism with environmental performance. These effects are more dominant in countries that are becoming richer and that introduce policies of adjustment and fight against pollution. These countries are geared towards more and more democratic policies. Findings proved that $\mathrm{H} 1-\mathrm{H} 9$ could be accepted and $\mathrm{H} 10$ - refused.

Author Contributions: For research articles with several authors, a short paragraph specifying their individual contributions must be provided. The following statements should be used conceptualization, D. H.; methodology, D. H.; software, D. H.; validation, D. H., and B. D. A.; formal analysis, D. H., and B. D. A.; investigation, D. H.; resources, D. H.; data curation, D. H.; writing-original draft preparation, D. H.; D. $\mathrm{H}$ - review and editing, , D. H., and B. D. A.; visualization, D. H., and B. D. A.; supervision, B. D. A project administration, B. D. A.; funding acquisition, B. D. A.

Funding: This research was funded by Deanship of Scientific Research, Northern Border University and The APC was funded by grant №(435/000).

\section{References}

Abou-Ali, H. and Y. M. Abdelfattah (2013). «Integrated paradigm for sustainable development: A panel data study». Economic Modelling 30(Supplement C): 334-342.

Agenor, P.-R. (2010). «A theory of infrastructure-led development». Journal of Economic Dynamics and Control 34(5): 932-950.

Ahmad, N., et al. (2017). «Modelling the CO2 emissions and economic growth in Croatia: Is there any environmental Kuznets curve?» Energy 123(Supplement C): 164-172.

Almeida, T. A. d. N., et al. (2017). «Economic growth and environmental impacts: An analysis based on a composite index of environmental damage». Ecological Indicators 76(Supplement C): 119-130. 
H. Dkhili, L. B. Dhiab. Environmental Management Efficiency of GCC Countries: Linking Between Composite Index of Environmental Performance, Socio-Political and Economic Dimensions

Al-mulali, U., et al. (2015). «Investigating the environmental Kuznets curve (EKC) hypothesis by utilizing the ecological footprint as an indicator of environmental degradation». Ecological Indicators 48(Supplement C): 315-323.

Alt, E. and H. Spitzeck (2016). «Improving environmental performance through unit-level organizational citizenship behaviors for the environment: A capability perspective». Journal of Environmental Management 182: 48-58.

Al-Tuwaijir, S. A., et al. (2004). «The relations among environmental disclosure, environmental performance, and economic performance: a simultaneous equations approach». Accounting, Organizations and Society 29(5-6): 447-471.

Arbolino, R., et al. (2018). «The policy diffusion of environmental performance in the European countries». Ecological Indicators 89: $130-138$.

Arellano, M. and O. Bover (1995). «Another look at the instrumental variable estimation of error-components models». Journal of Econometrics 68(1): 29-51.

Arora, V. and S. Shi (2016). «Energy consumption and economic growth in the United States». Applied Economics 48(39): 3763-3773.

AsICl, A. A. (2013). "Economic growth and its impact on environment: A panel data analysis». Ecological Indicators 24(Supplement C): 324-333

Azam, M. (2016). «Does environmental degradation shackle economic growth? A panel data investigation on 11 Asian countries». Renewable and Sustainable Energy Reviews 65(Supplement C): 175-182.

Barrett, S. (2006). «Climate Treaties and «Breakthrough» Technologies». American Economic Review 96(2): 22-25.

Barrett, S. and K. Graddy (2000). «Freedom, growth, and the environment». Environment and Development Economics 5(4): 433-456.

Benchekroun, H. and A. Ray Chaudhuri (2014). «Transboundary pollution and clean technologies». Resource and Energy Economics 36(2): 601-619.

Bilgen, S. (2014). «Structure and environmental impact of global energy consumption». Renewable and Sustainable Energy Reviews 38: 890-902

Bohringer, C. and P. Jochem (2007). «Measuring the immeasurable - A survey of sustainability indices». Ecological Economics

63(1): 1-8

Bond, P. (1999). «Basic infrastructure for socio-economic development, environmental protection and geographical desegregation: South Africa's unmet challenge». Geoforum 30(1): 43-59.

Bravo, G. (2014). «The Human Sustainable Development Index: New calculations and a first critical analysis». Ecological Indicators 37(Part A): 145-150.

Carrion-Flores, C. E. and R. Innes (2010). «Environmental innovation and environmental performance» Journal of Environmental Economics and Management 59(1): 27-42.

Caviglia-Harris, J. L., et al. (2009). «Taking the «U» out of Kuznets: A comprehensive analysis of the EKC and environmental degradation». Ecological Economics 68(4): 1149-1159.

Chapman, L. (2007). «Transport and climate change: a review». Journal of Transport Geography 15(5): 354-367.

Chikalipah, S. (2017). «Institutional Environment and Microfinance Performance in Sub-Saharan Africa». African Development Review 29(1): 16-27.

Cho, C. H., et al. (2010). "The language of US corporate environmental disclosure». Accounting, Organizations and Society 35(4): 431-443

Congleton, R. D. and R. W. Bennett (1995). «On the political economy of state highway expenditures: Some evidence of the relative performance of alternative public choice models». Public Choice 84(1): 1-24.

Cracolici, M. F., et al. (2009). «The Measurement of Economic, Social and Environmental Performance of Countries: A Nove Approach». Social Indicators Research 95(2): 339.

Dahl, R. A. (1994). «A Democratic Dilemma: System Effectiveness versus Citizen Participation». Political Science Quarterly 109(1): 23-34.

Distaso, A. (2007). "Well-being and/or quality of life in EU countries through a multidimensional index of sustainability».

Ecological Economics 64(1): 163-180.

Dobbie, M. J. and D. Dail (2013). «Robustness and sensitivity of weighting and aggregation in constructing composite indices».

Ecological Indicators 29: 270-277.

Dubois, G. and J.-P. Ceron (2006). «Tourism and Climate Change: Proposals for a Research Agenda». Journal of Sustainable Tourism 14(4): 399-415.

Duit, A., and al. (2009). «Saving the Woodpeckers: Social Capital, Governance, and Policy Performance» The Journal of Environment \& Development 18(1): 42-61.

Ebert, U. and H. Welsch (2004). «Meaningful environmental indices: a social choice approach». Journal of Environmental Economics and Management 47(2): 270-283.

Echavarren, J. M. (2017). «From Objective Environmental Problems to Subjective Environmental Concern: A Multilevel Analysis Using 30 Indicators of Environmental Quality». Society \& Natural Resources 30(2): 145-159.

Garcia-Sanchez, I.-M., et al. (2015). «A proposal for a Composite Index of Environmental Performance (CIEP) for countries». Ecological Indicators 48(Supplement C): 171-188. 
H. Dkhili, L. B. Dhiab. Environmental Management Efficiency of GCC Countries: Linking Between Composite Index of Environmental Performance, Socio-Political and Economic Dimensions

Giannone, D. (2010). «Political and ideological aspects in the measurement of democracy: the Freedom House case». Democratization 17(1): 68-97.

Gil-Molto, M. J. and D. Varvarigos (2013). «Emission taxes and the adoption of cleaner technologies: The case of environmentally conscious consumers». Resource and Energy Economics 35(4): 486-504.

Gupta, A. (2010). «Transparency as Contested Political Terrain: Who Knows What about the Global GMO Trade and Why does it Matter?» Global Environmental Politics 10(3): 32-52.

Hansen, G. S. and B. Wernerfelt (1989). «Determinants of firm performance: The relative importance of economic and organizational factors». Strategic Management Journal 10(5): 399-411.

Hickman, R., et al. (2010). «Transport and climate change: Simulating the options for carbon reduction in London». Transport Policy 17(2): 110-125

Husted, B. W. and J. M. d. Sousa-Filho (2017). «The impact of sustainability governance, country stakeholder orientation, and country risk on environmental, social, and governance performance». Journal of Cleaner Production 155(Part 2): 93-102.

Jamali, D., et al. (2017). «CSR logics in developing countries: Translation, adaptation and stalled development». Journal of World Business 52(3): 343-359.

Kerret, D., et al. (2014). "Green perspective for a hopeful future: Explaining green schools' contribution to environmental subjective well-being». Review of General Psychology 18(2): 82-88.

Kim, S., et al. (2017). «The impacts of weather on tourist satisfaction and revisit intention: a study of South Korean domestic tourism». Asia Pacific Journal of Tourism Research 22(9): 895-908.

Lucas, K. (2011). «Making the connections between transport disadvantage and the social exclusion of low income populations in the Tshwane Region of South Africa». Journal of Transport Geography 19(6): 1320-1334.

Mukherjee, S. and D. Chakraborty (2013). «Is environmental sustainability influenced by socioeconomic and sociopolitical factors? cross-country empirical evidence». Sustainable Development 21(6): 353-371.

Murakami, F., et al. (2015). «How the Brazilian government can use public policies to induce recycling and still save money?» Journal of Cleaner Production 96: 94-101.

NEUMAYER, E. (2002). «Do Democracies Exhibit Stronger International Environmental Commitment? A Cross-country Analysis». Journal of Peace Research 39(2): 139-164.

Obiedkov, S., et al. (2013). «A Multidimensional Model for Analyzing Democratic Development in Central and Eastern Europe.» Transition Studies Review 20(2): 191-209.

O'Ryan, R., et al. (2005). «Computable general equilibrium model analysis of economywide cross effects of social and environmental policies in Chile». Ecological Economics 54(4): 447-472.

Payne, R. A. (1995). Freedom and the Environment. Journal of Democracy 6(3), 41-55. Johns Hopkins University Press. Retrieved March 23, 2018, from Project MUSE database.

R. Lopezand S. Mitra (2000). «Corruption, Pollution, and the Kuznets Environment Curve». Journal of Environmental Economics and Management 40(2): 137-150

Schultink, G. (2000). «Critical environmental indicators: performance indices and assessment models for sustainable rural development planning». Ecological Modelling 130(1): 47-58.

Scruggs, L. (1999). «Institutions and Environmental Performance in Seventeen Western Democracies». British Journal of Political Science 29(01): 1-31.

Swamy, A. and B. Fikkert (2002). "Estimating the Contributions of Capital and Labor to GDP: An Instrumental Variable Approach». Economic Development and Cultural Change 50(3): 693-708.

Tamazian, A. and B. Bhaskara Rao (2010). «Do economic, financial and institutional developments matter for environmenta degradation? Evidence from transitional economies». Energy Economics 32(1): 137-145.

Tarverdi, Y. (2018). «Aspects of Governance and $\mathrm{CO}_{2}$ Emissions: A Non-linear Panel Data Analysis». Environmental and Resource Economics 69(1): 167-194.

Tol, R. S. J. (2009). «The Economic Effects of Climate Change». Journal of Economic Perspectives 23(2): 29-51.

Wang Xu-Mei. (2010). «Optimization of DNA isolation, ISSR-PCR system and primers screening of genuine species of rhubarb an important herbal medicine in China». Journal of Medicinal Plants Research 4.10: 904-908.

Wang, S., et al. (2016). «Sustainable Development in China's Coastal Area: Based on the Driver-Pressure-State-WelfareResponse Framework and the Data Envelopment Analysis Model». Sustainability 8(9): 958.

Welsch, H. (2007). «Environmental welfare analysis: A life satisfaction approach». Ecological Economics 62(3): 544-551.

Wolsink, M. (2010). «Contested environmental policy infrastructure: Socio-political acceptance of renewable energy, water, and waste facilities». Environmental Impact Assessment Review 30(5): 302-311.

York, R. and B. Clark (2010). «Critical Materialism: Science, Technology, and Environmental Sustainability ${ }^{\star} »$. Sociological Inquiry 80(3): 475-499. 
H. Dkhili, L. B. Dhiab. Environmental Management Efficiency of GCC Countries: Linking Between Composite Index of Environmental Performance, Socio-Political and Economic Dimensions

X. Дкхілі, Північний прикордонній університет (Саудівська Аравія), Університет Джендуба (Туніс),

Л. Б. Дхіаб, Північний прикордонній університет (Саудівська Аравія).

Ефективність екологічного менеджменту в країнах Перської затоки: взаємозв'язок між інтегральним індексом ефективності екологічної політики, соціальними, політичними та економічними детермінантами

Стаття присвячена аналізу передумов розробки та впровадження інноваційних механізмів підвищення ефеективності управління екологічною політикою країн Перської затоки. Основною метою дослідження $є$ визначення взаємозв'язку між інтегральним індексом ефективності управління екологічною політикою, соціальними, політичними та економічними детермінантами розвитку країн Перської затоки. У статті проаналізовано та систематизовано науково-методичні підходи до визначення характеру та сили впливу інтегрального індексу ефективності управління екологічною політикою на соціальнополітичні та економічні детермінантами розвитку країн. Авторами запропоновано використовувати економетричну модель для розрахунку інтегрального індексу ефективності екологічної політики. При цьому інтегральний індекс ефективності екологічної політики розглядається як залежна змінна від економічних (технологічний процес, транспорт, інфраструктура, споживання товарів, міжнародна торгівля та туризм) та соціальних (демократія, свобода, відкритість органів влади та соціальна політика) детермінант розвитку країн. Емпіричне дослідження проведено на основі панельних даних сформованих для вибірки з 6 країн за 2002-2016 рр. Для аналізу панельних даних авторами використано узагальнений метод найменших квадратів. За результатами дослідження авторами доведено, що демократія, соціальна політика та відкритість органів влади мають статистично значимий позитивний вплив на рівень ефеективності екологічної політики. При цьому змінні індикатори транспорт, інфраструктура та туризм мають статистично значимий негативний вплив на рівень еффективності екологічної політики. Таким чином, результати дослідження підтверджують висунуту гіпотезу про наявність взаємозв'язку між ефективністю екологічної політики і соціальними, політичними та економічними детермінантами розвитку країн Перської затоки. Авторами наголошено, що, отримані результати дослідження мають практичне значення для науковців, що досліджують механізми підвищення ефективності управління екологічною політикою країни за умови збалансування соціальних, політичних та економічних детермінант розвитку країн. Крім цього, результати дослідження можуть бути корисними для країн, які включать інтегральний індекс ефективності екологічної політики до своїх національних стратегій розвитку.

Ключові слова: інтегральний індекс ефективності екологічної політики, соціально-політичні детермінанти, економічні детермінанти, узагальнений метод найменших квадратів, країни Перської затоки.

Manuscript received: 11.12.2018

(c) The author(s) 2019. This article is published with open access at Sumy State University. 